\title{
Using remote sensing to assess tsunami-induced impacts on coastal forest ecosystems at the Andaman Sea coast of Thailand
}

\author{
H. Roemer ${ }^{1}$, G. Kaiser ${ }^{1}$, H. Sterr ${ }^{1}$, and R. Ludwig ${ }^{2}$ \\ ${ }^{1}$ Department of Geography, Christian-Albrechts-Universität zu Kiel, Kiel, Germany \\ ${ }^{2}$ Department of Geography, Ludwig-Maximilians-Universität München, Munich, Germany
}

Received: 22 December 2009 - Revised: 16 March 2010 - Accepted: 20 March 2010 - Published: 13 April 2010

\begin{abstract}
The December 2004 tsunami strongly impacted coastal ecosystems along the Andaman Sea coast of Thailand. In this paper tsunami-induced damage of five different coastal forest ecosystems at the Phang-Nga province coast is analysed with a remote sensing driven approach based on multi-date IKONOS imagery. Two change detection algorithms, change vector analysis (CVA) and direct multi-date classification (DMC), are applied and compared regarding their applicability to assess tsunami impacts. The analysis shows that DMC outperforms CVA in terms of accuracy (Kappa values for DMC ranging between 0.947 and 0.950 and between $0.610-0.730$ for CVA respectively) and the degree of detail of the created change classes. Results from DMC show that mangroves were the worst damaged among the five forests, with a 55\% of directly damaged forest in the study area, followed by casuarina forest and coconut plantation. Additionally this study points out the uncertainties in both methods which are mainly due to a lack of ground truth information for the time between the two acquisition dates of satellite images. The created damage maps help to better understand the way the tsunami impacted coastal forests and give basic information for estimating tsunami sensitivity of coastal forests.
\end{abstract}

\section{Introduction}

The Indian Ocean Tsunami in 2004 was one of the most devastating natural disasters ever. Besides the enormous number of fatalities and the massive destruction of settlements and infrastructure, coastal ecosystems were deteriorated or

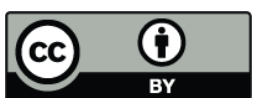

Correspondence to: H. Roemer (roemer@geographie.uni-kiel.de) destroyed (e.g. Szczucinski et al., 2006; Phongsuwan et al., 2006). At the Andaman Sea coast of Thailand, the PhangNga province was one of the most severely affected regions. For instance, in total 386 ha of mangrove forests were impacted directly by the tsunami (Paphavasit et al., 2009), other coastal forests were uprooted or washed away, coral reefs were affected in various ways, and beaches as well as tidal inlets were eroded (e.g. Paphavasit et al., 2009; DMCR, 2005). There are some studies from Thailand referring to the assessment of tsunami impacts on coastal forests. Most of them are based on field work, e.g. measurements conducted by the Department of Marine and Coastal Resources (e.g. DMCR, 2005, 2006; DMCR and Thammasat University, 2005) or by UNEP (UNEP, 2005) or the Office of Natural Resources and Environmental Policy and Planning (ONEP) (ONEP, 2005). Some studies focus on the impacts on mangrove forests (Yanagisawa et al., 2009a, b; Paphavasit et al., 2009) and on the role of mangroves acting as natural buffers in mitigating tsunami impacts (Danielsen et al., 2005; Chang et al., 2006; Chatenoux and Peduzzi, 2007; Tanaka et al., 2006).

On a larger spatial scale, remote sensing based studies were conducted in Thailand in order to provide a quick damage assessment: Vu et al. (2007) used a dual-scale approach based on ASTER and IKONOS imagery, while Kouchi and Yamazaki (2007) used a digital elevation model and spectral indices (NDVI, NDWI, NDSI) developed from ASTER pre- and post-tsunami data. Other remote sensing studies refer to specific ecosystems like mangroves: Bahugana et al. (2008) analyse tsunami impacts on coral reefs and mangroves at the Andaman and Nicobar Islands using an unsupervised post-classification approach based on multi-temporal RESOURCESAT and AWiFS data. Damage assessment of mangroves based on SPOT pansharpened imagery has been conducted for Phang-Nga by Deeudomchan

Published by Copernicus Publications on behalf of the European Geosciences Union. 

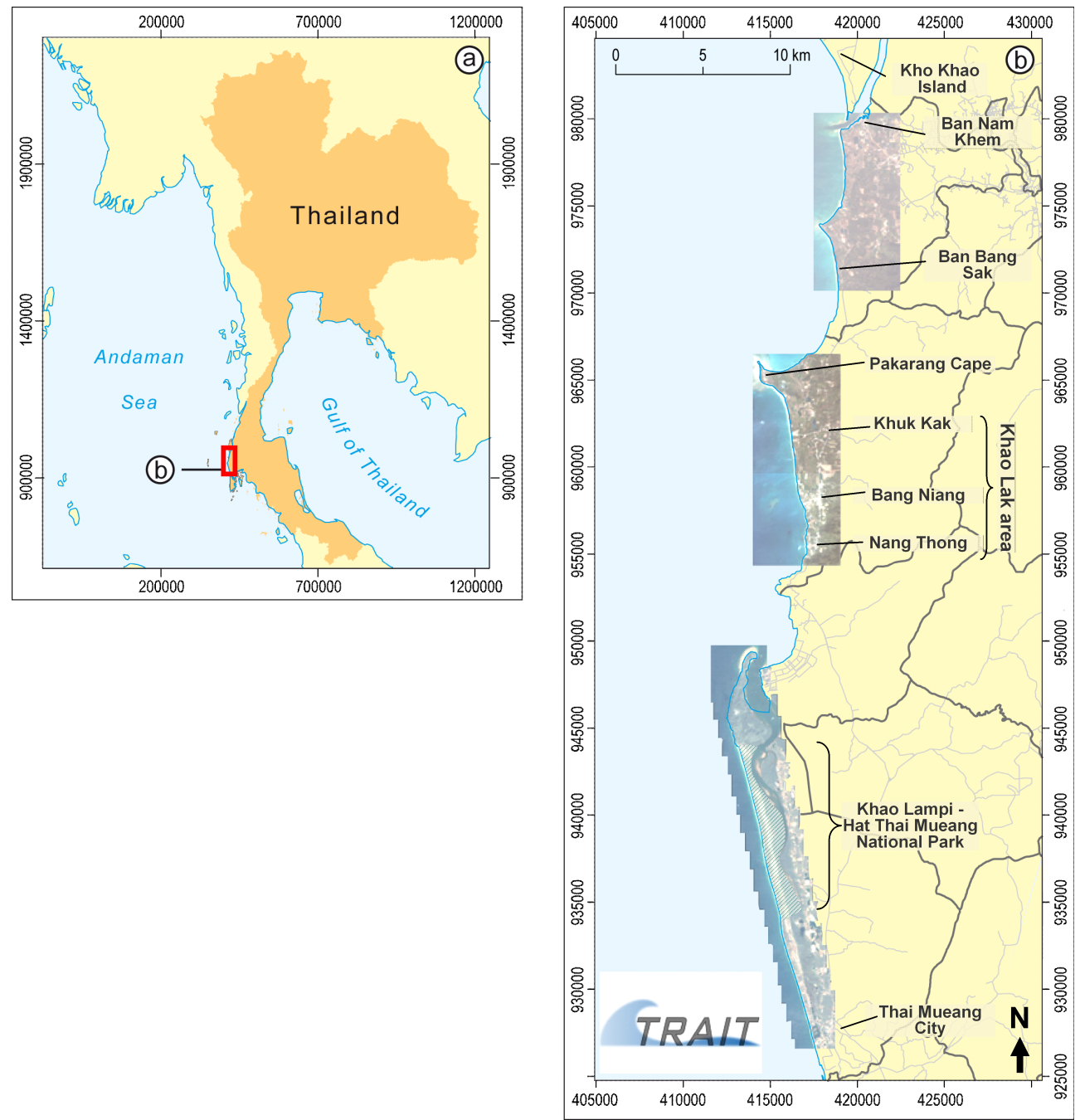

Fig. 1. Study area. Satellite images are based on IKONOS multispectral data from 13 January 2003. The administrative units are at the community level (muban).

et al. (2006). It was found that mangroves along the shores were impacted more strongly than those in the inner areas. A combined approach based on change detection techniques (Landsat TM) and GIS proximity analysis was presented by Sirikulchayanon et al. (2008).

In this study, tsunami-related impacts are determined from satellite image analyses for five different coastal forest ecosystems (including mangrove forests, casuarina beach forests, mixed beach forests, melaleuca forest and coconut plantation). Two different change detection techniques (change vector analysis, CVA, and direct multi-date classification, DMC) are compared. Thus, this study contributes to the general need for studies focussing on comparative evaluations of change detection studies (Mas, 1999). DMC (Weissmiller et al., 1977; Mas, 1999) was applied respectively for the red, green and near-infrared bands in the multidate dataset; the CVA (e.g. Malila, 1980; Johnson, 1994) was applied for the first two tasseled cap components brightness and greenness, which were calculated from all four multispectral bands (Horne, 2003).

The results of this study help to better understand the way coastal forests have been impacted by the tsunami and thus provide a further step for in-depth-assessments of ecological and socio-ecological tsunami sensitivity of the coastal area.

\section{Study area}

The study area (Fig. 1) covers a $50 \mathrm{~km}$ long coastal strip in the Phang-Nga province in Thailand from Ban Nam Khem in the north to Thai Mueang city in the south. The area was strongly impacted by the 2004 tsunami: Along the coast between Khao Lak and the northern tip of Kho Khao Island, runup heights were in the range of 5.0 to $10.0 \mathrm{~m}$ and the 


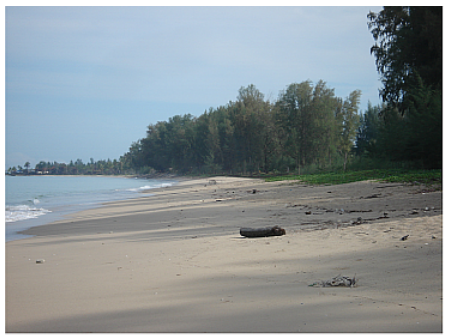

casuarina beach forest Casuarina equiesetifolia, Barringtonia asiatica, Pandanus odoratissimus

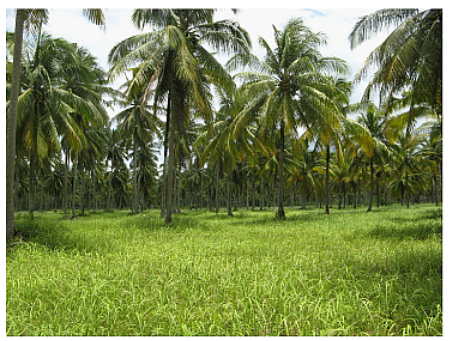

coconut plantation

cocos nucifera

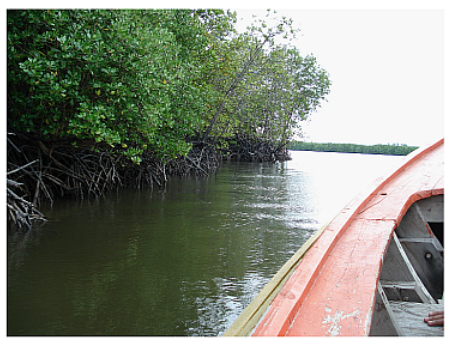

mangrove forest

Rhizophora sp., Bruguiera sp., Ceriops sp.

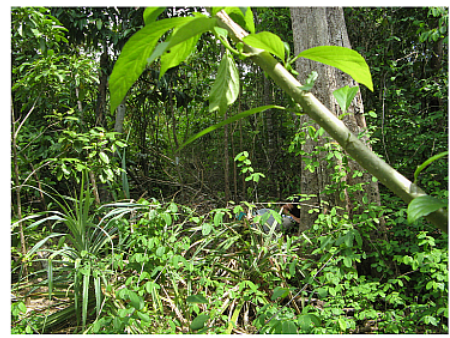

mixed beach forest

Syzigium grande, Shorea sp., Eugenia sp., Diospyros sp.

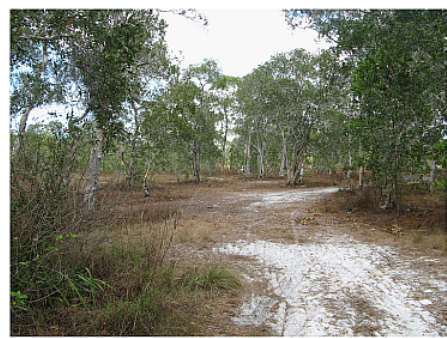

melaleuca forest

Melaleuca leucadendron

Fig. 2. Coastal forest ecosystems examined in the study (photos taken in January 2009).

inundation varied from $200 \mathrm{~m}$ around Ban Bang Sak beach to more than $1.5 \mathrm{~km}$ at Pakarang Cape. Run up at Khao Lampi Hat Thai Mueang National Park (here called as Thai Mueang National Park) was slightly lower, ranging from 3.5 to $6.5 \mathrm{~m}$ (Szczucinski et al., 2006; Ioualalen et al., 2007).

The sparsely populated northern part of the study area $\left(8^{\circ} 52^{\prime} 10^{\prime \prime} \mathrm{N}\right.$ to $\left.8^{\circ} 46^{\prime} 30^{\prime \prime} \mathrm{N}\right)$ is dominated by agriculture (rubber, oil palm and coconut plantation, orchards). Further to the south, Khao Lak (the area between $8^{\circ} 44^{\prime} 30^{\prime \prime}$ and $8^{\circ} 37^{\prime} 52^{\prime \prime}$ ) represents a young booming tourism community with large hotel complexes scattered near the coast around the touristic villages Khuk Kak, Bang Niang and Nang Thong. The southern part $\left(8^{\circ} 35^{\prime} 15^{\prime \prime} \mathrm{N}\right.$ to $\left.8^{\circ} 28^{\prime} 28^{\prime \prime}\right)$ is located on a peninsula around a tidal inlet and hosts large areas of intact coastal ecosystems like mangroves, beach forests and primary rain forest on the mountainous northern tip of the peninsula. The Thai Mueang National Park covers a main part of this peninsula. The whole study area is interspersed with smaller freshwater ponds resulting from tin mining activities during the last century (Williams et al., 1996; Szczucinski et al., 2006).

The topography of the coastal area is relatively flat, with elevations mostly below $20 \mathrm{~m}$ a.s.l. Coasts are predominantly built-up by sand. A sequence of beach ridges occurs in many coastal areas. They are usually up to $2 \mathrm{~m}$ high and aligned in parallel to the beach. These ridges often alternate with linear swampy depressions termed swales. Rocky coasts occur north of Thai Mueang National Park at the northern tip of the peninsula and south of the Khao Lak area (Pajimans, 1976).

Regarding the vegetation characteristics, five coastal forests can be distinguished (Fig. 2): mangrove forests, casuarina beach forests, coconut plantation, mixed beach forest and melaleuca forests. Mangrove forests can be found in different places in the study area, mostly along the river mouths near Thai Mueang National Park. Other river mangroves occur near Ban Nam Khem and Pakarang Cape. The total area of mangrove forests within the tsunami inundation zone was about 108 ha. Rhizophora apicculata, R. mucronata, Ceriops tagal, Bruguiera sp. are the dominant species (Yanagisawa et al., 2009a; Phapavasit et al., 2009).

Casuarina equisetifolia is a common pioneer (Ipomoea pes-caprae formation) in beach ridges and flat environments and forms $20-30 \mathrm{~m}$ wide mono-specific stands above the high water-mark on sandy coasts, river mouths and offshore bars (Cochard et al., 2008; Pajimans, 1976; Wong, 2005). The total forest area is 76 ha.

Coconut plantations (Cocos nucifera), with a total area of 451 ha, can be found in many places along the coast, especially in the Khao Lak area and near Ban Nam Khem. Being strongly influenced by human interventions, it is not to be considered a natural forest (Kashio, 2005).

Mixed littoral forest (termed mixed beach forest in the following) is located in Thai Mueang National Park covering a total area of 130 ha. The forest is very dense at uniform 
Table 1. IKONOS band dependent parameters of the scenes acquired on 13 January 2003, 04:11 GMT (pre-tsunami) and 15 January 2005 04:12 GMT (post-tsunami), after Taylor (2009), Geoeye (2006).

\begin{tabular}{|c|c|c|c|c|}
\hline $\begin{array}{l}\text { IKONOS } \\
\text { band } \\
(\lambda)\end{array}$ & $\begin{array}{l}\text { spectral } \\
\text { range } \\
(\mathrm{nm})\end{array}$ & $\begin{array}{l}\text { band- } \\
\text { width } \\
(\mathrm{nm})\end{array}$ & $\begin{array}{l}\text { resolution } \\
(\mathrm{m}) \\
\text { nadir } / 26^{\circ} \\
\text { off nadir }\end{array}$ & $\begin{array}{l}\mathrm{CalCoef}_{\lambda}^{*} \\
(\mathrm{DN} /(\mathrm{mW} / \\
\left.\left.\mathrm{cm}^{2}-\mathrm{sr}\right)\right)\end{array}$ \\
\hline Pan & $526-929$ & 403 & $0.82 / 1.0$ & 161 \\
\hline Blue & $445-516$ & 71.3 & $3.2 / 4.0$ & 728 \\
\hline Green & $506-595$ & 88.6 & $3.2 / 4.0$ & 727 \\
\hline Red & $632-698$ & 65.8 & $3.2 / 4.0$ & 949 \\
\hline NIR & $757-853$ & 95.4 & $3.2 / 4.0$ & 843 \\
\hline
\end{tabular}

* Only for image production date Post 22 February 2001 (coefficients are for the 11-bit products).

canopy height. Typical canopy trees are Syzigium grande, Diospyros sp., Shorea sp., Lepisanthes rubigunosa, Eugenia $\mathrm{sp}$. The mixed beach forest directly borders to the melaleuca savannah (here called melaleuca forest), which is dominated by Melaleuca leucadendron. This widely spaced forest type covers a small area of 42 ha in Thai Mueang National Park.

\section{Data and methods}

The study used multi-date IKONOS images (Table 1) acquired on 13 January 2003 (pre-tsunami) and on 15 January 2005 (post-tsunami). All change detection techniques in this paper were carried out on the multispectral bands with a resolution of about four meters, whereas the higher resolution pan-sharpened data ( $1 \mathrm{~m}$ horizontal resolution) were used for validation purposes.

In order to distinguish between different types of coastal forest, a land use map was created from the pre-tsunami IKONOS image by object oriented image analysis (using Definiens Developer 7.0 software). With a total number of 42 different land use classes, the map provides information on the spatial distribution of mangrove forests, casuarina beach forests, mixed beach forests, melaleuca forest and coconut plantation. The forest polygons were used to reduce the classified pixel quantity from $2.76 \times 10^{7}$ to $5.04 \times 10^{5}$.

\section{Image processing}

\subsection{Pre-processing}

Before applying change detection analyses, the digital numbers from IKONOS imagery $\left(\mathrm{DN}_{\lambda}\right)$ were converted into at sensor's aperture radiance values $\left(L_{\lambda}\right)$, according to the equation (Taylor, 2009):
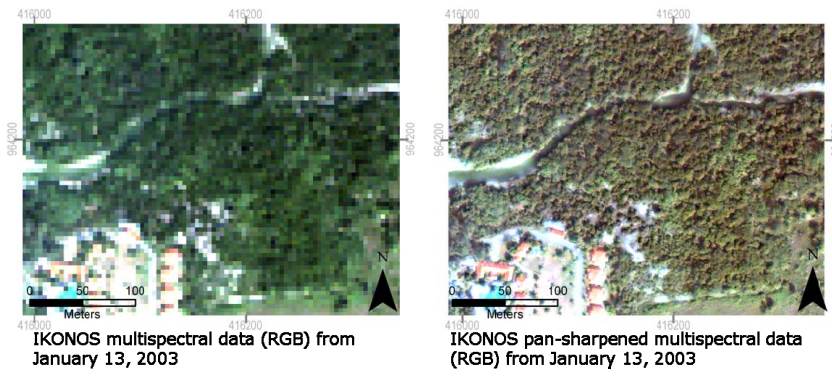

Fig. 3. IKONOS pan-sharpening based on the Gram-Schmidtspectral sharpening technique (northern Khao Lak).

$$
L_{\lambda}=\frac{10^{4} \cdot \mathrm{DN}_{\lambda}}{\operatorname{CalCoef}_{\lambda} \cdot \text { Bandwidth }_{\lambda}},
$$

where,

$\mathrm{DN}_{\lambda}=$ digital value for spectral band $\lambda$,

CalCoef $_{\lambda}=$ Radiometric calibration coefficient $\left(\mathrm{DN} /\left(\mathrm{mW} / \mathrm{cm}^{2}-\mathrm{sr}\right)\right)$

Bandwidth $_{\lambda}=$ Bandwidth of spectral band $\lambda(\mathrm{nm})$.

Both CalCoef ${ }_{\lambda}$ and Bandwidth $\lambda$ are given in Table 1.

Geometric correction (co-registration) was carried out by using a set of ground control points from the pre-tsunami scene. The post-tsunami scene was then warped to the base image. The dark object subtraction, one of the simplest and most widely used image-based absolute atmospheric correction approaches, was applied for radiometric correction (Spanner et al., 1990; Ekstrand, 1994).

Image pan-sharpening was applied using the GramSchmidt Spectral Sharpening approach (Laben and Brower, 2000). Therewith, the low resolution multispectral data (4 m) were sharpened using the high spatial resolution panchromatic band $(1 \mathrm{~m})$. The resulting high-resolution multispectral dataset (Fig. 3) was used to visually select training areas and for identifying appropriate test sites for the accuracy assessment of change classifications.

\subsection{Change detection}

\subsubsection{Direct multi-date classification}

The direct multi-date classification is performed according to the scheme in Fig. 4, starting with the definition of appropriate change classes and training areas.

Pan-sharpened IKONOS imagery as well as several studies on tsunami driven impacts on coastal ecosystems (Yanagisawa et al., 2009a; Phapavasit et al., 2009; Bechteler et al., 2006) revealed that coastal forests were damaged in different ways and intensities. As illustrated in Fig. 5, forest damage patterns were categorized in four major damage classes including (1) no/low damage, (2) direct forest damage, (3) indirect forest damage, and (4) degradation of understory 
Table 2. Training and test area for DMC.

\begin{tabular}{|c|c|c|c|c|}
\hline \multicolumn{2}{|c|}{ Change classes (ID/name) } & \multirow{2}{*}{$\begin{array}{l}\text { Training area } N^{*} \\
460\end{array}$} & \multirow{2}{*}{$\begin{array}{l}\text { Aggregated change classes } \\
\text { no damage }\end{array}$} & \multirow{2}{*}{$\begin{array}{l}\text { Test area } \mathrm{N}^{*} \\
988\end{array}$} \\
\hline 1 & persistence vegetation & & & \\
\hline 2 & persistence sand & 109 & & \\
\hline 3 & understory vegetation $\rightarrow$ soil & 29 & degradation of soils/understory vegetation & 59 \\
\hline 4 & understory $\rightarrow$ sand/sandy soils & 18 & & \\
\hline 5 & understory $\rightarrow$ water & 163 & & \\
\hline 6 & sand $\rightarrow$ water & 97 & & \\
\hline 7 & mud $\rightarrow$ water & 123 & & \\
\hline 8 & soil $\rightarrow$ sand & 97 & & \\
\hline 9 & forest $\rightarrow$ mud & 295 & direct forest damage & 143 \\
\hline 10 & forest $\rightarrow$ sand & 330 & & 148 \\
\hline 11 & forest $\rightarrow$ water & 314 & & 187 \\
\hline 12 & forest $\rightarrow$ inclined/roots rem. & 80 & & 145 \\
\hline 13 & yellowing/standing leafless & 248 & indirect forest damage: yellowing/standing leafless & 261 \\
\hline
\end{tabular}

* = number of pixels (total number of image pixels $5.04 \times 10^{5}$ pixels).

vegetation and soils. Direct forest damage is closely related to the kinetic energy of massive water flows caused by the tsunami. Additionally it can be distinguished between a) a total removal of trees (termed as "forest to sand/water/mud") or b) uprooting or inclination of trees without removal. Indirect tree damage, not affecting the physical structure of stem and branches (Bechteler et al., 2006; Obura and Abdulla, 2005), is understood for trees showing symptoms of toxic and water stress, such as yellowing, drying leaves or defoliation (due to sediment deposition or salt water intrusion). For those areas which are not covered by tree canopies, damage information obtained from satellite images are directly related to changes of soils and understory vegetation. Thus, a new class "degradation of soils/understory" was created. Of course this does not imply that understory vegetation or soils were unaffected in damage classes 2 and 3.

The definition of training and test areas was carried out based on the high resolution pan-sharpened imagery. As illustrated in Table 2, a total of 13 different training classes (6360 pixels) were selected, organized in eight super classes. Test areas (1931 pixel) were selected independently and only for the aggregated super-classes. Since the five forest types have different stand densities (low density in melaleuca forests and coconut plantations) and were impacted in different ways (e.g. direct impacts were rare in mixed beach forests), not all change classes could be selected as training areas in each of the five forest ecosystems. Figure 6 exemplifies the selection of seven different change sub-classes.

Pre- and post-tsunami IKONOS data capture four multispectral bands (Table 1). Since not all multispectral bands contain the same information, while adjacent bands in the visual domain are closely correlated (and therefore partly redundant), a preliminary step in image classification involves the definition of optimum multi-spectral band composition.

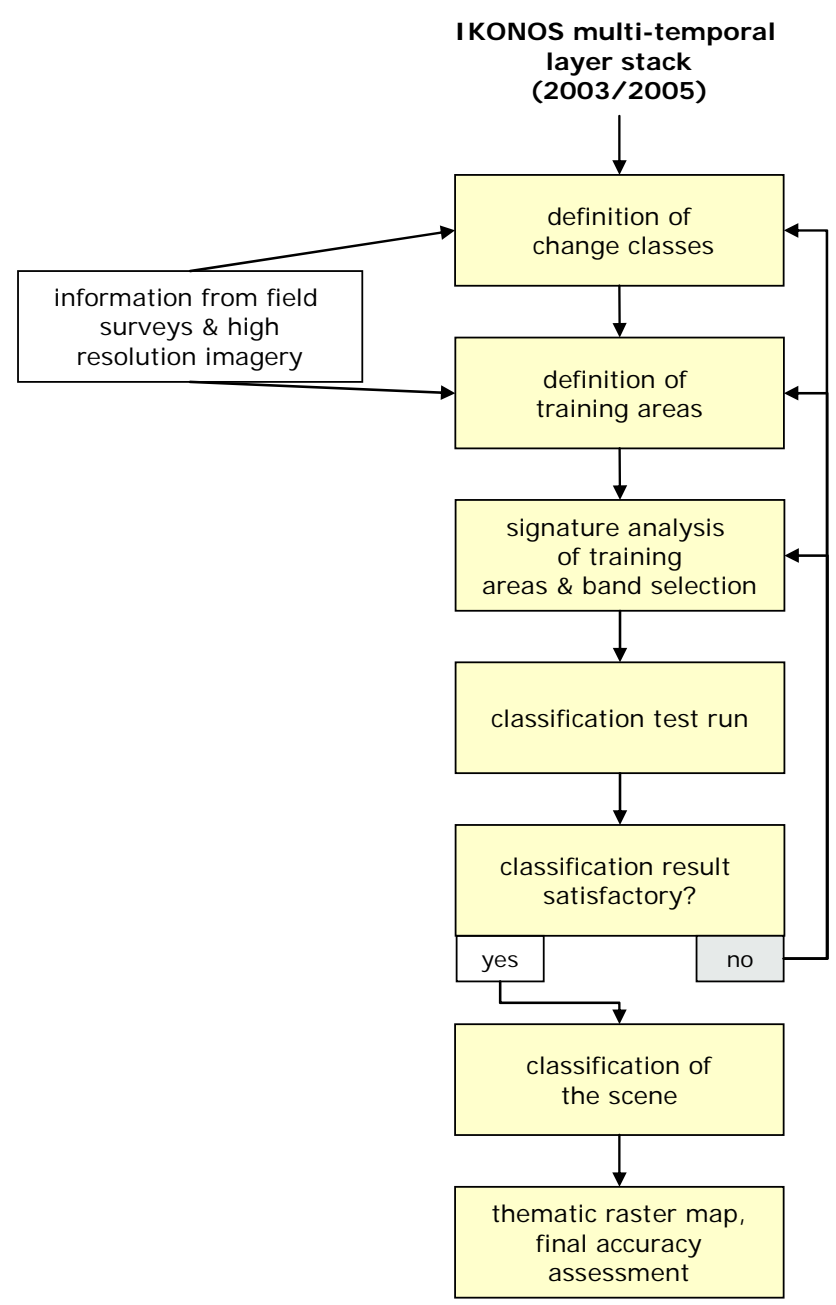

Fig. 4. Flowchart of direct multi-date supervised classification. 


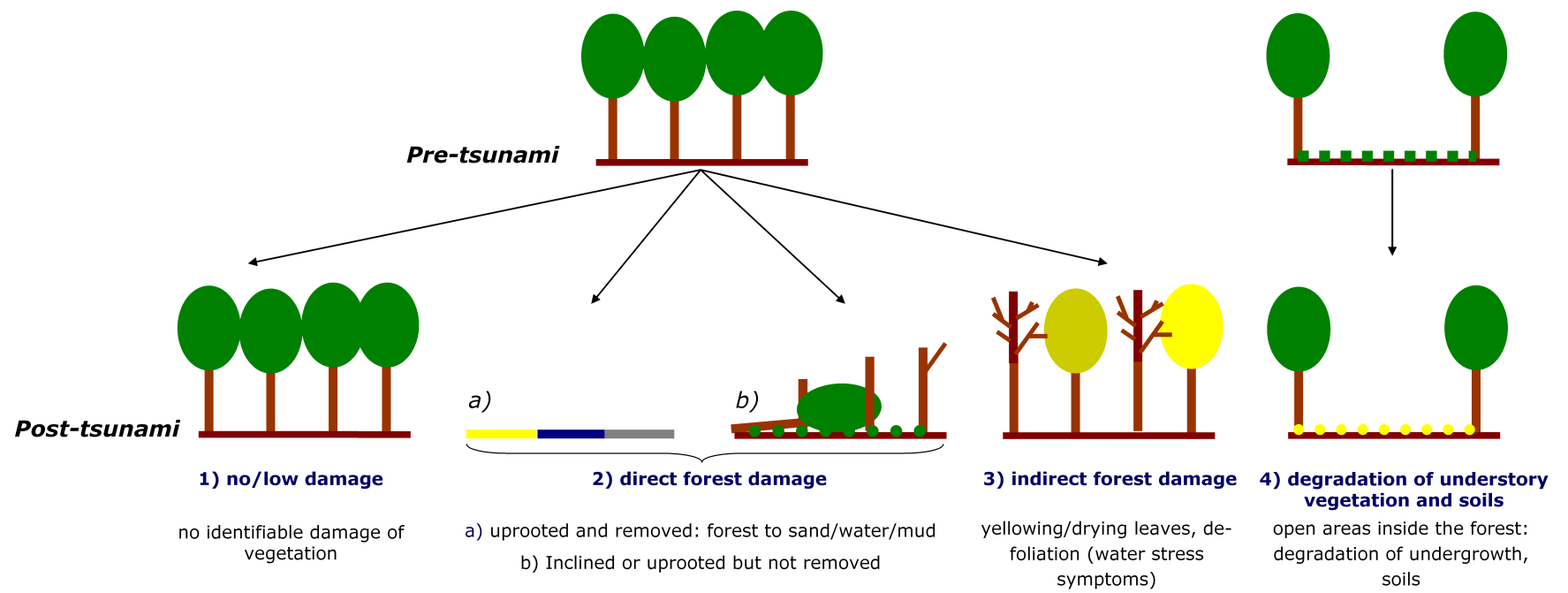

Fig. 5. Categorization of forest damage patterns.

a)

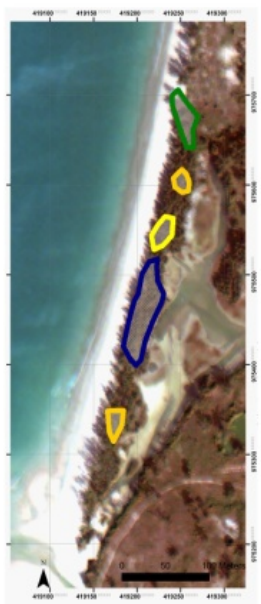

pre-tsunami

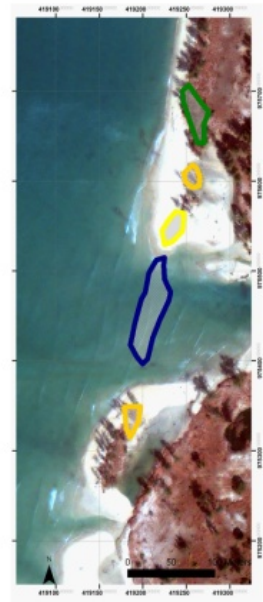

post-tsunami b)

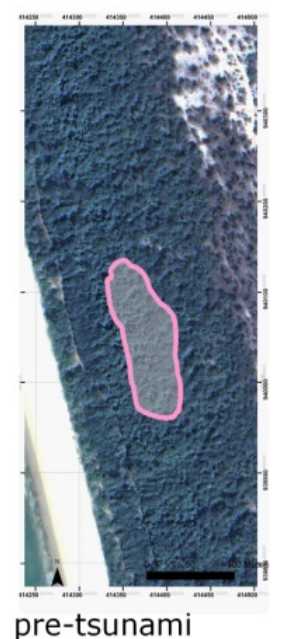

indirect forest damage: yellowing / defoliation c)
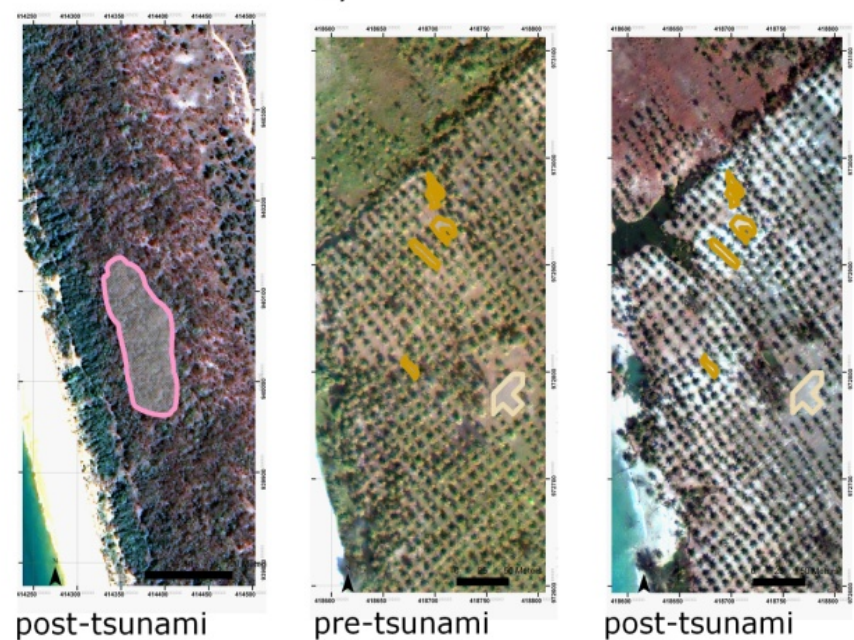

post-tsunami

direct forest damage: forest to water direct forest damage: forest to sand direct forest damage: uprooted; roots/trunks remaining no damage of vegetation

Fig. 6. Selection of training areas exemplified for seven different change classes. (a) casuarina beach forest near Ban Bang Sak, (b) mixed beach forest in Thai Mueang, and (c) coconut plantation near Ban Bang Sak.

Table 3. OIF calculation for multi-date IKONOS imagery.

\begin{tabular}{llll}
\hline band composites* $^{*}$ & OIF 2003 & OIF 2005 & mean OIF \\
\hline $1 / 2 / 3$ & 16.08 & 21.66 & 18.87 \\
$1 / 2 / 4$ & 43.98 & 43.74 & 43.86 \\
$1 / 3 / 4$ & 44.59 & 47.64 & 46.12 \\
$2 / 3 / 4$ & 49.16 & 43.57 & 46.37 \\
\hline
\end{tabular}

* bands 1-4: 1 = blue, 2 = green, $3=$ red, $4=$ near infrared .
The Optimum Index Factor (OIF), determined as the ratio of band contrast and band correlation (Chavez et al., 1982) was calculated for both multispectral datasets. High OIF values indicate band combinations with high information content. According to Table 3, the highest values correspond to the composite containing the green, red and near infrared band for the pre-tsunami scene and the blue, red and near infrared band for the post-tsunami scene. In order to avoid using two different three-band combinations for multi-date classification, we used the combination with the highest mean OIF in 
Table 4. Change class definition based on CVA.

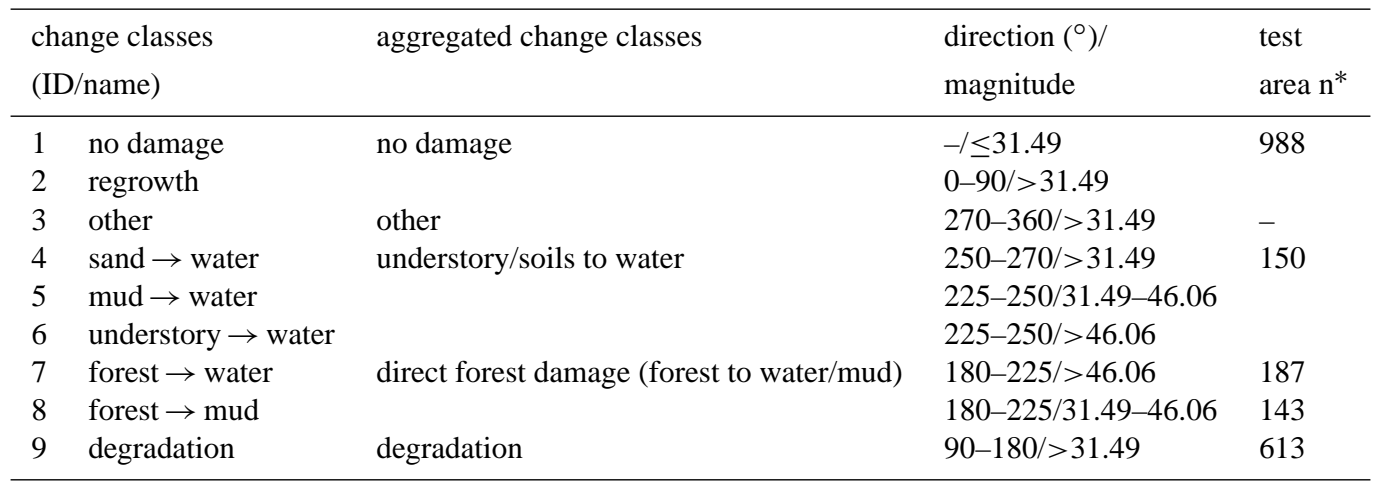

$=$ number of pixels (total number of image pixels $5.04 \times 10^{5}$ pixels).

both scenes (compare to Table 2). The final band composite for multi-data classification contains the green, red and near-infrared bands in both scenes.

\subsubsection{Change Vector Analysis (CVA)}

A first step of CVA involves the calculation of the tasseled cap components brightness (TC 1) and greenness (TC 2), in order to reduce the amount of redundant information of digital images to be analyzed (Kauth and Thomas, 1976). This process can be compared to defining a new two-dimensional feature space, in which the multispectral data occupy two new axis associated with biophysical properties in the areas of interest. According to Lorena et al. (2002), the brightness axis is correlated to variations of soil reflectance whereas the greenness axis is associated with amount and vitality of vegetation. Tasseled cap components were calculated for IKONOS multispectral data according to the equations (Horne, 2003):

TC $1=0.326 \cdot x_{\text {blue }}+0.509 \cdot x_{\text {green }}+0.560 \cdot x_{\text {red }}+0.567 \cdot x_{\text {nir }}$,

TC $2=-0.311 \cdot x_{\text {blue }}-0.356 \cdot x_{\text {green }}-0.325 \cdot x_{\text {red }}+0.819 \cdot x_{\text {nir }}$,

where TC 1 and TC 2 are the tasseled cap components brightness and greenness and $x$ represents the value of the respective multispectral band. The position variation of the same pixel during different data acquisitions within the twodimensional space can be determined by the magnitude and direction of the spectral change vectors. The vector's magnitude was calculated using the Euclidean distance between the positions of a pixel within the feature space of different data acquisitions, using the equation:

$R=\sqrt{(y a-y b)^{2}+(x a-x b)^{2}}$

where $R$ is the Euclidean distance, $y a$ and $y b$ are the greenness values from January 2005 and January 2003 respec- tively, and $x a$ and $x b$ the brightness values from January 2005 and January 2003, respectively.

The direction or angle of the change vector is determined by the type of occurring change. Due to the fact that only two components are used for CVA, only four major change directions are possible:

- 0-90 : increase in both components,

- 90-180 : increase in brightness, decrease in greenness,

- 180-270 : decrease in both components,

- 270-360 : decrease in brightness and increase in greenness.

Similar to a decision tree classification, the final definition of change classes (Table 4) was carried out by user defined thresholds of direction and magnitude values. Spectral statistics of training areas, computed for the multi-date classification (Sect. 4.2.1), were used for decision support (Fig. 7). The threshold distinguishing between change- and no-change-information (31.49) was defined based on the first standard deviation from the mean magnitude calculated for training class IDs 1 and 2 (Table 2). Another threshold of 46.06 was defined based on 1.5 times the standard deviation of the vector's magnitude.

A differentiation between damage of understory vegetation and damage of forests was restricted to the third quadrant between 180 and $270^{\circ}$ of the feature space. Thus, the change class defined in the second quadrant "degradation" contains multiple types of land cover changes as defined in DMC including the class IDs 3, 4, 8, 10, 12, and 13 from Table 2.

Except for the change classes 4-6 (understory/soils to water), the same test areas from DMC could be used again. The test area for the class "degradation" is composed of four different test areas resulting from the change class IDs 3, 4, 8, 10,12 , and 13 . 


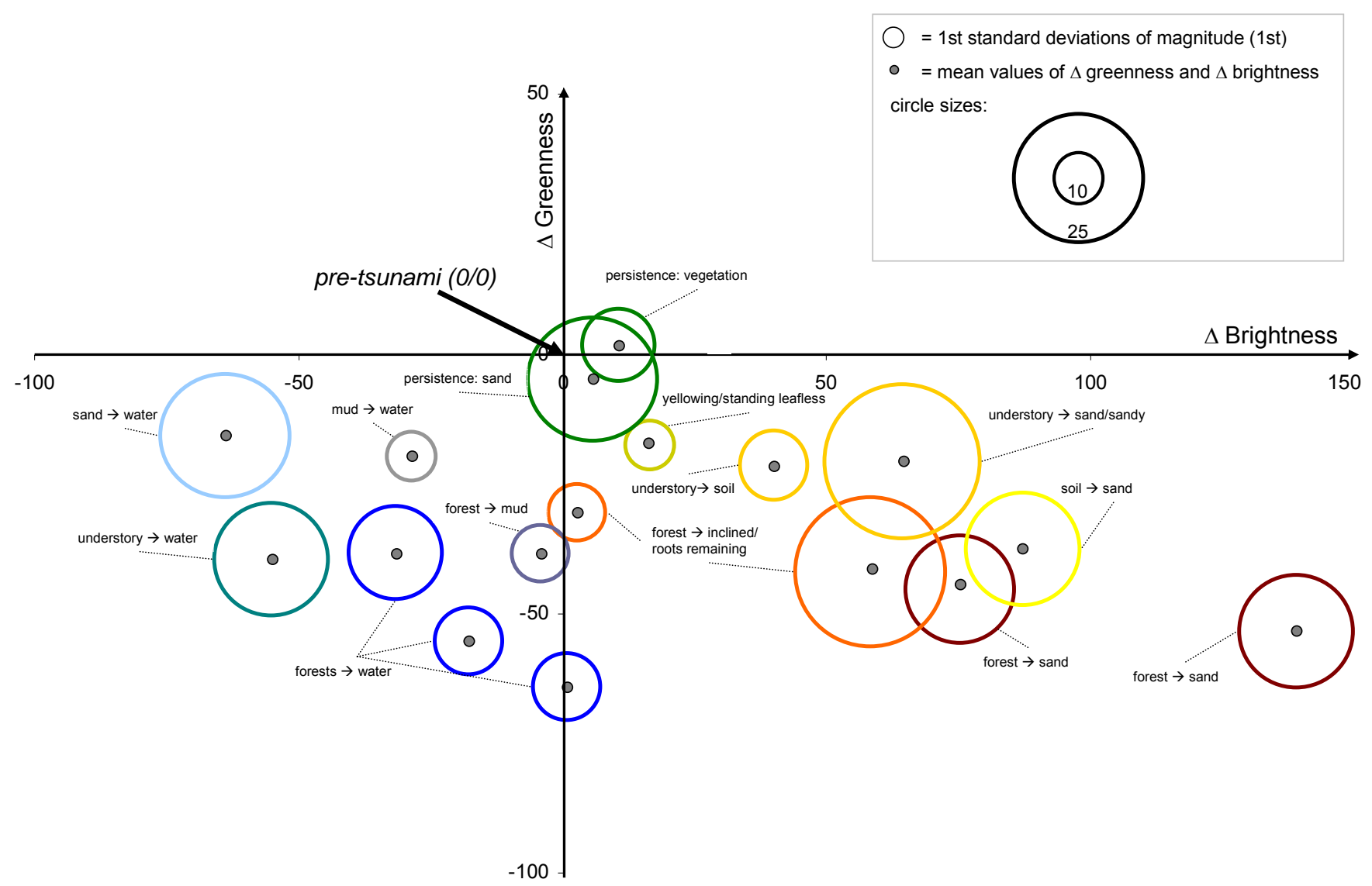

Fig. 7. Training classes from DMC displayed in a two dimensional feature space.

Table 5. Damage statistics (area in \%) based on DMC.

\begin{tabular}{lrrrrr}
\hline $\begin{array}{l}\text { damage } \\
\text { type }\end{array}$ & $\begin{array}{r}\text { mangrove } \\
\text { forests }\end{array}$ & $\begin{array}{r}\text { casuarina } \\
\text { beach forest }\end{array}$ & $\begin{array}{r}\text { coconut } \\
\text { plantation }\end{array}$ & $\begin{array}{r}\text { mixed } \\
\text { beach forest }\end{array}$ & $\begin{array}{r}\text { melaleuca } \\
\text { forest }\end{array}$ \\
\hline forest $\rightarrow$ sand & 22.67 & 27.10 & 21.04 & 0.35 & 0.73 \\
forest $\rightarrow$ water & 3.42 & 4.94 & 0.88 & 0.13 & 0.47 \\
forest $\rightarrow$ mud & 23.37 & 0.27 & 0.12 & 0.48 & 0.00 \\
forest inclined/roots remaining & 4.17 & 5.67 & 5.59 & 0.29 & 0.02 \\
indirect damage & 7.52 & 1.69 & 3.52 & 52.90 & 21.36 \\
degradation of soils/understory & 4.97 & 13.72 & 34.24 & 1.10 & 15.85 \\
no damage & 32.05 & 45.52 & 34.58 & 44.76 & 61.68 \\
other & 0.31 & 1.08 & 0.03 & 0.00 & 0.00 \\
total area (ha) & 107.90 & 75.90 & 451.00 & 130.10 & 42.20 \\
\hline
\end{tabular}

\section{Results}

\subsection{Direct multi-date classification}

Damage statistics for all the five forest types are illustrated in Table 5 (aggregated, except for direct forest damage) and Fig. 8 (aggregated). It can be concluded that damage patterns vary among the five coastal forest ecosys- tems: mangroves were the most damaged forest type with a total of 60 ha of forest area directly damaged (change classes 9-12, see Table 2). This relates to $55 \%$ of the initial mangrove area located within the inundation zone. Indirect damage, such as drying and yellowing of leaves or defoliation occurred mainly in mixed beach forests and melaleuca forests. These forests types are exclusively located in Thai Mueang National park where wave energy 
Table 6. Damage statistics based on CVA.

\begin{tabular}{lrrrrr}
\hline $\begin{array}{l}\text { damage } \\
\text { type } \\
\text { (area in \%) }\end{array}$ & $\begin{array}{r}\text { mangrove } \\
\text { forests }\end{array}$ & $\begin{array}{r}\text { casuarina } \\
\text { beach forest }\end{array}$ & $\begin{array}{r}\text { coconut } \\
\text { plantation }\end{array}$ & $\begin{array}{r}\text { mixed } \\
\text { beach forest }\end{array}$ & $\begin{array}{r}\text { melaleuca } \\
\text { forest }\end{array}$ \\
\hline understory/soils $\rightarrow$ water & 0.32 & 0.35 & 0.59 & 0.04 & 0.33 \\
forest $\rightarrow$ mud & 4.80 & 0.86 & 1.0 & 3.93 & 0.03 \\
forest $\rightarrow$ water & 23.37 & 3.13 & 1.43 & 3.54 & 0.03 \\
degradation & 33.48 & 42.7 & 61.70 & 7.69 & 7.01 \\
no damage & 38.03 & 52.71 & 35.12 & 84.78 & 91.61 \\
other & 0 & 0.30 & 0.16 & 0.02 & 1.76 \\
total area (ha) & 107.90 & 75.90 & 451.00 & 130.10 & 42.20 \\
\hline
\end{tabular}

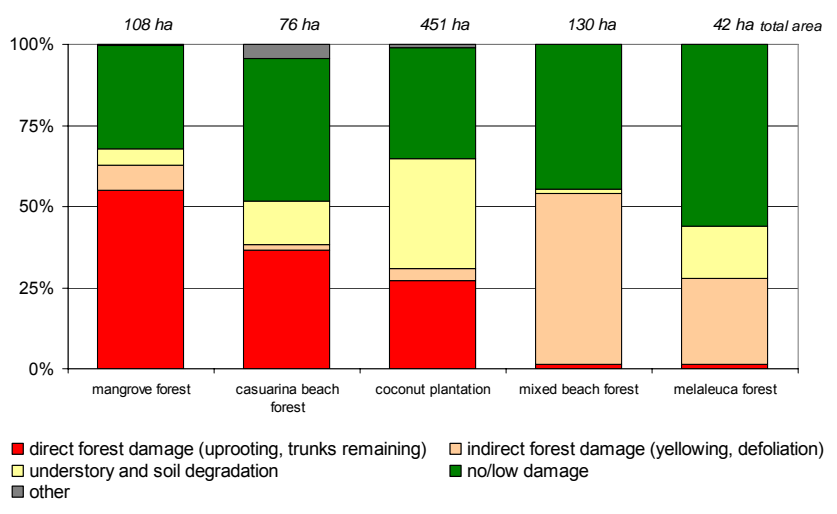

Fig. 8. Damage patterns based on direct-multi-date classification.

was relatively low (Ioualalen et al., 2007). Casuarina beach forests were also severely damaged by the tsunami, with $38 \%$ of direct damage. Tsunami induced direct damage to coconut plantation is very likely overestimated, due to man made changes which have taken place between image acquisition dates. Damage of understory and soils is maximal in coconut plantation and melaleuca forest, where forest stand densities are usually low. Melaleuca forest was least damaged with approximately $62 \%$ of the area classified as "no/low damage" and about $16 \%$ as "understory or soil degradation".

Spatial patterns of forest damage are shown in Fig. 9 for selected subsets. As illustrated in maps (a) and (d), severe damage occurred particularly near the rivers (blue areas). This is very likely related to the higher intensity of the tsunami backwash which was channelled and accelerated in river valleys. In example (e) a sand dune was completely breached. As a consequence, the tin mining pond in the back side of the dune has evolved to a small bay. Indirect tsunami impact on mixed beach forests are concentrated more in the hinterland than near the coast, probably a consequence of the present swales in this area. Another reason could be a change in species composition towards a higher abundance of salt-intolerant species. The figure also illustrates (c) that melaleuca forests were only slightly affected by the tsunami.

The quality of change detection results was examined based on test areas $(\mathrm{N}=1931)$ as described in Table 2. An overall accuracy of $96.4 \%$ and a Kappa value of 0.947 indicate very good results. Confusion matrices are shown in Appendix A.

\subsection{Change vector analysis}

Because CVA is based on the combined examination of vector's magnitude and direction, the isolated examination of both measures, as illustrated in Fig. 10, provide low information on the kind and intensity of forest damage.

Damage statistics derived from CVA are given in Table 6 and Fig. 11 for the aggregated classes. As already pointed out in DMC, $91.61 \%$ of the melaleuca forest area has been classified as "no damage", closely followed by mixed beach forest with $84.5 \%$. From the statistics it can be assumed that coconut plantations are the most damaged and thus most sensitive forest type in this study. Only $35 \%$ of the coconut area is classified as "no damage", followed by mangroves with 38\%. But without knowing the relation between understory or soil damage and direct tree damage, any assumptions concerning the actual forest damage are uncertain. Direct forest damage including "forest to water" and "forest to mud" occurred mainly in mangroves $(28.17 \%)$, followed by mixed beach forest $(7.5 \%)$ which is neither consistent with visual interpretation of pan-sharpened IKONOS imagery nor with findings from literature.

Spatial patterns of forest damage are shown in Fig. 12 for selected subsets. As pointed out in Fig. 9, severe direct damage to forest trees such as the class "forest to water" particularly occurred near the river mouths (Fig. 12a and e) or near the shore (Fig. 12d). In CVA the class "degradation" includes both, damage to understory vegetation or soils and damage to trees, which complicates the estimation of the damaged forest area. An accuracy assessment was carried out based on five test areas (2081 pixels) as described in Table 4. With 


\section{Damage pattern analysis based on DMC}

\begin{tabular}{|l}
\hline forest-->sand \\
inclined/trunks remaining \\
no/low damage \\
\hline understory and soil degradation \\
forest-->water \\
forest-->mud \\
\hline yellowing, defoliation
\end{tabular}
a) mangrove forest
b) mixed beach forest
c) melaleuca forest
d) coconut plantation
e) casuarina beach forest

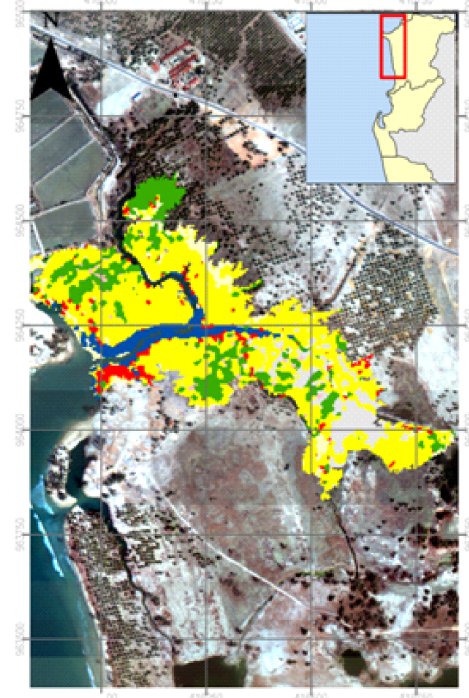

a

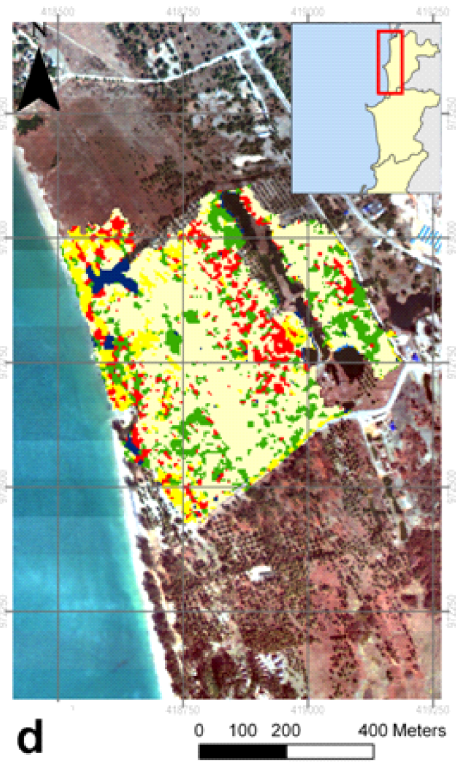

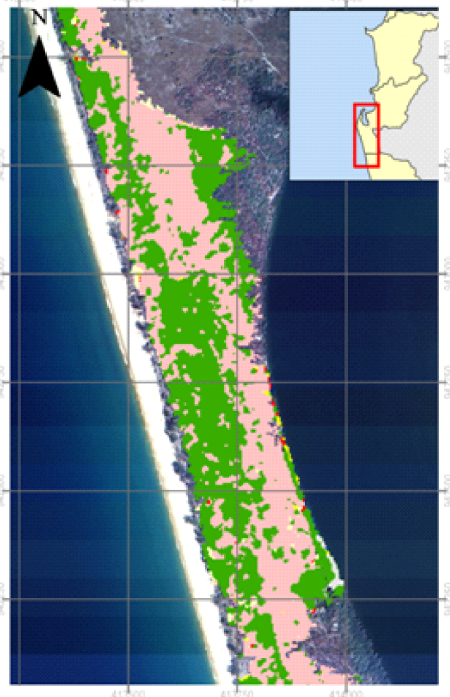
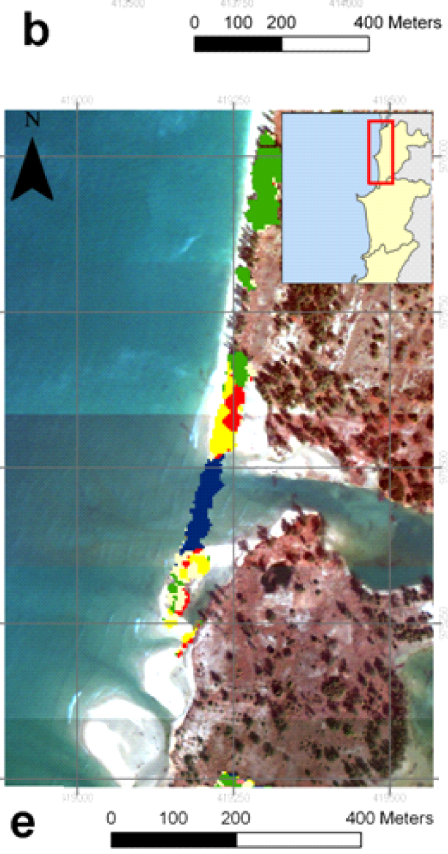

Fig. 9. Change maps based on DMC, illustrated for the five coastal forests in the Phang-Nga province.
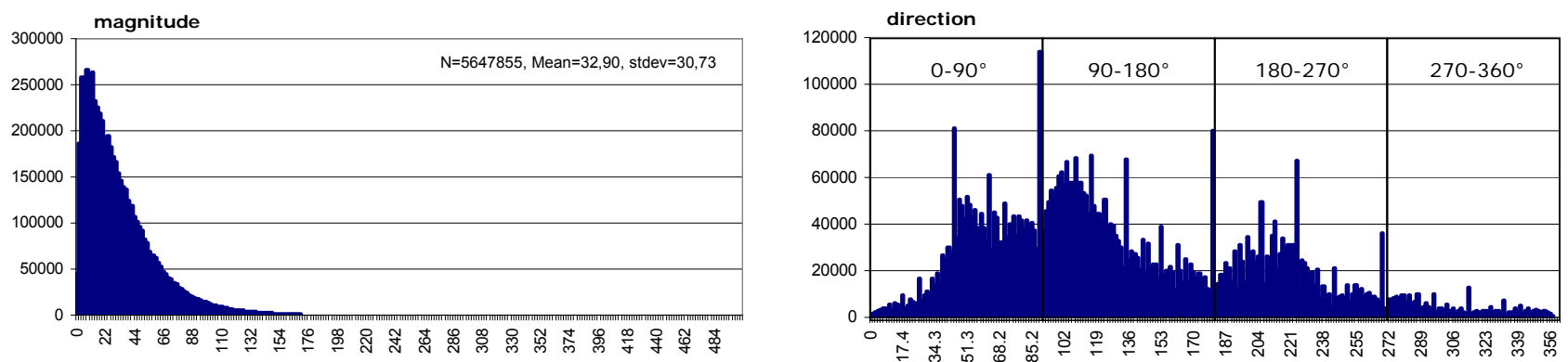

Fig. 10. Frequency distributions of change vector's magnitude and direction. 


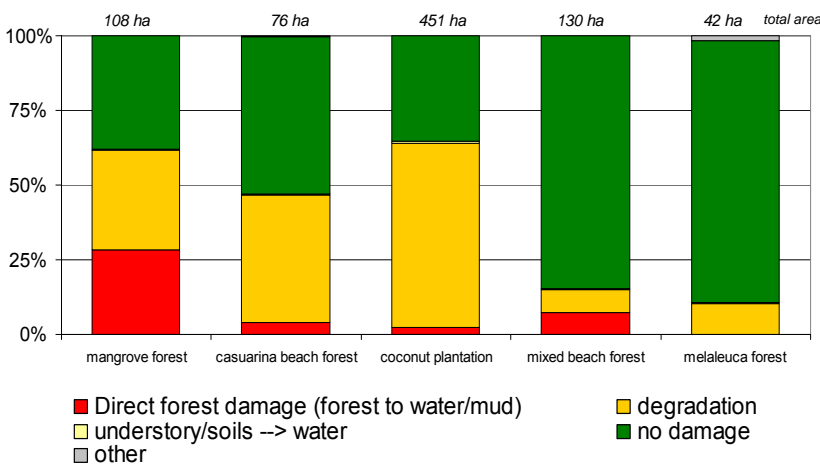

Fig. 11. Damage patterns based on CVA.

an overall accuracy of $68.62 \%$ and a Kappa value of 0.61 , CVA led to satisfactory to sufficient results. Inaccuracies mainly appear for the class "degradation" (producer accuracy of $43 \%$ ) where $39 \%$ of pixels were incorrectly classified as "no damage". This becomes clear in Fig. 12b, where large areas which were damaged indirectly by the tsunami (see Fig. 9b) are now classified as "no damage". Confusion matrices for CVA are listed in Appendix B.

\section{Discussion}

Assessing ecological vulnerability of coastal forests requires a good understanding of the damage caused by the tsunami. Since damage patterns vary in space and are determined by different influencing factors, such as distance to shoreline and rivers, elevation or coast inclination, detailed spatial damage information was derived for the whole coastal area between Ban Nam Khem in the North and Thai Mueang in the South. The two methods applied here showed different results, varying according to accuracy, expenditure of work and usefulness for vulnerability assessment.

\subsection{Accuracy}

As pointed out in Sect. 5, DMC provides much more accurate results than CVA in terms of information content and clearness of the created change classes and the calculated accuracy for the change maps (96.4\% for DMC and $68.6 \%$ for CVA, respectively). Thus, damage assessment based on DMC is much more precise, especially for low density forests such as coconut plantations. The accuracy of the change detection results was also audited by aggregating change classes in one no-damage class and one damage class (cp. Table 7 and Appendices C and D). Although accuracy measures are closer than in the disaggregated approach in Sect. 5, DMC still provides more accurate results than CVA. It becomes clear that the total damage area is underestimated in CVA. This problem resulted from the difficulty of select- ing an adequate threshold distinguishing between changeand no-change information, as described in Sect. 4.2.2.

Figure 13 shows that an underestimation of damage particularly occurs for melaleuca forests and mixed beach forest. These forest types have been predominantly damaged only slightly and indirectly.

\subsection{Expenditure of time and work}

Although technical implementation of CVA is easier than DMC, both methods require producer's expertise in order to correctly interpret change detection results. Disadvantages in DMC involve the problem of considering many different types of change classes during the classification process and the fact that the degree of automation is relatively low. Performing CVA is quicker in the beginning phase, since rough change information can be automatically extracted from the change vector's magnitude and direction. The challenge here lies in the selection of appropriate change thresholds and further differentiations of change classes (interpretation). Thus, expenditure of time and work is almost the same for both methods with some advantages for CVA.

\subsection{Transferability and implementation}

While being slightly more complex than CVA regarding expenditure of time and work, DMC provides more accurate results and is thus preferable for image based damage analysis. From this work it can be concluded that digital change detection techniques like CVA and DMC allow the estimation of ecological damages and are suited for ecological vulnerability assessment. Moreover it becomes clear that the selection of an adequate change detection technique is a crucial step when using remote sensing techniques to analyse forest damage. The usage of the high resolution IKONOS imagery is appropriate, because accurate spatial information of forest damage can be provided. Especially for the small patches of casuarina forests, it must be expected that the application of medium resolution imagery like ASTER $(15 \mathrm{~m})$ or Landsat ETM+ $(30 \mathrm{~m})$ would not have led to satisfactory results.

The application of remote sensing and digital change detection induces uncertainties which have to be taken into account when interpreting the results: Due to a lack of in-situ information on land use changes occurring between the first image acquisition date and the tsunami, land cover changes cannot be automatically related to tsunami induced impacts. Especially in the case of coconut plantations, human interventions may have occurred in this period. This problem may lead to an overestimation of the calculated damage area for coconut plantation, as illustrated in Fig. 14. Furthermore, there is a lack of more detailed spatial damage information, which cannot be sufficiently derived from satellite data, such as information on changes in soil conditions or damage information for specific plant species. 


\section{Damage pattern analysis based on CVA}

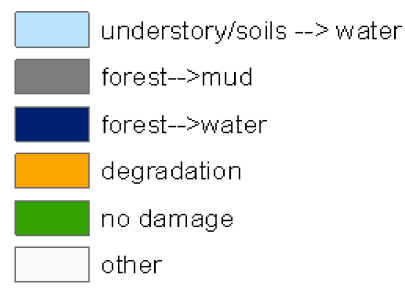

a) mangrove forest

b) mixed beach forest

c) melaleuca forest

d) coconut plantation

e) casuarina beach forest

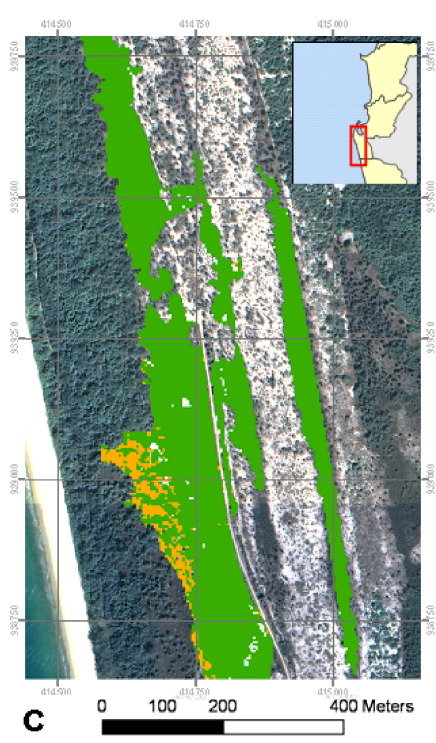

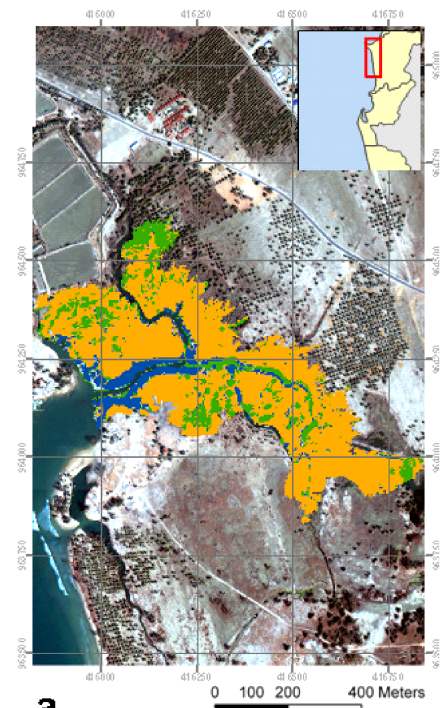

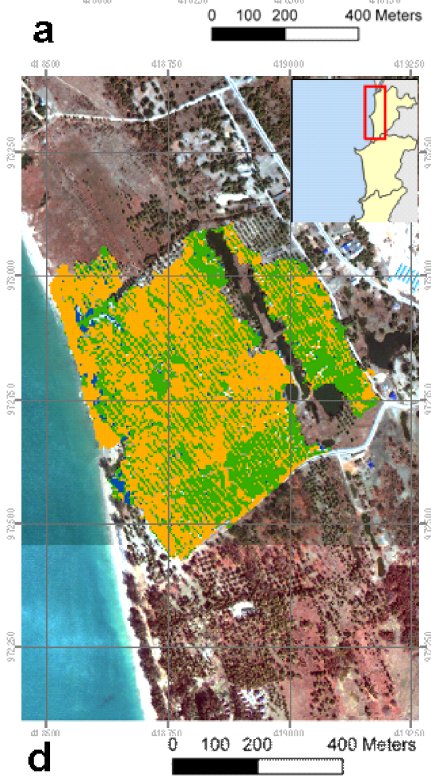

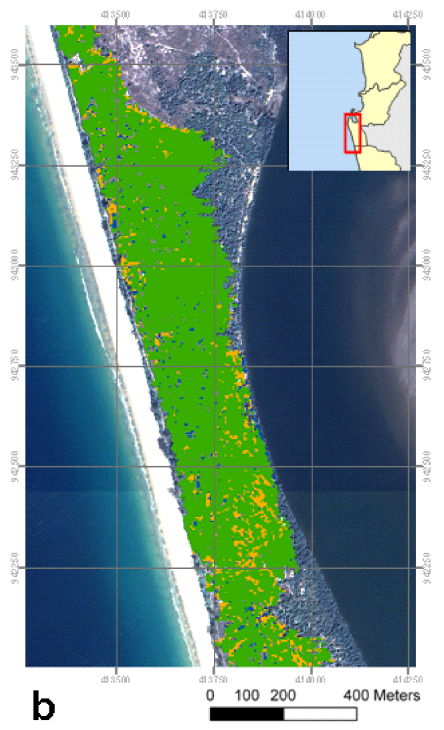
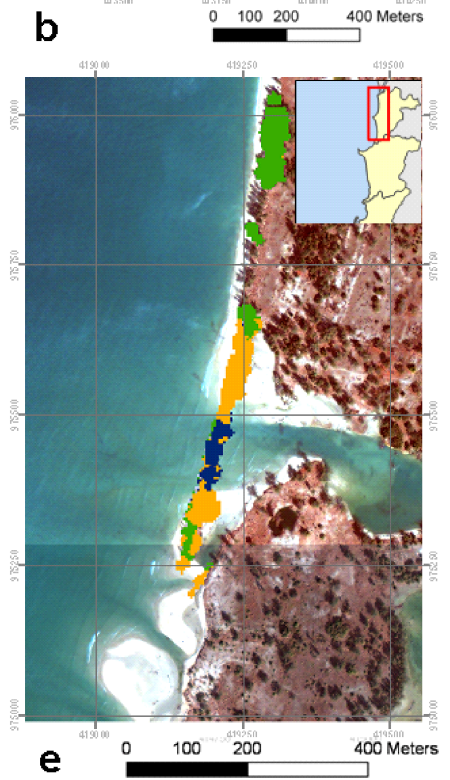

Fig. 12. Change maps based on CVA, illustrated for the five coastal forests in the Phang-Nga province.

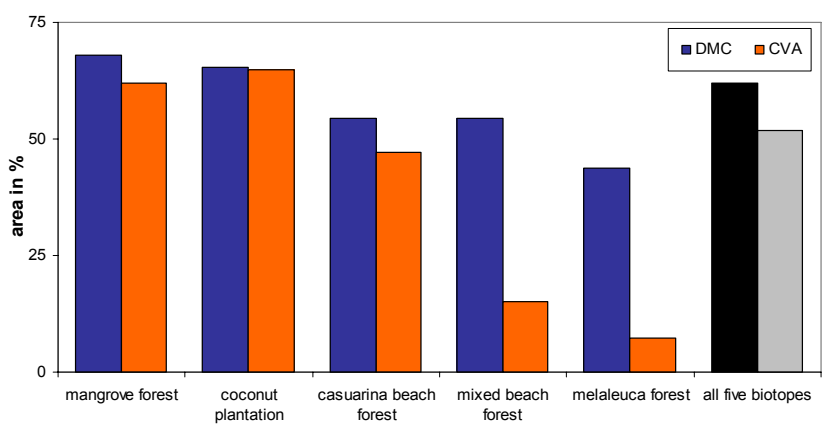

Fig. 13. Estimated damaged area for different forest types based on DMC and CVA.

\section{Concluding remarks}

This paper presents a remote sensing based approach for estimating tsunami induced impacts on coastal forests. The damage maps help to better understand the tsunami impact on coastal forest ecosystems. Additionally they provide valuable information to estimate tsunami sensitivity of coastal forests. It was emphasized that the accuracy of the results provided by digital change detection strongly depends on the respective technique. DMC clearly is the more effective and accurate change detection method, since a complex matrix of change information, so called from-to information, can be provided. For CVA, change information depends heavily on the selection of suitable thresholds (cp. Lu et al., 2004). This analysis showed that there are limitations in both methods, resulting from poor image data availability for the year 2004, 

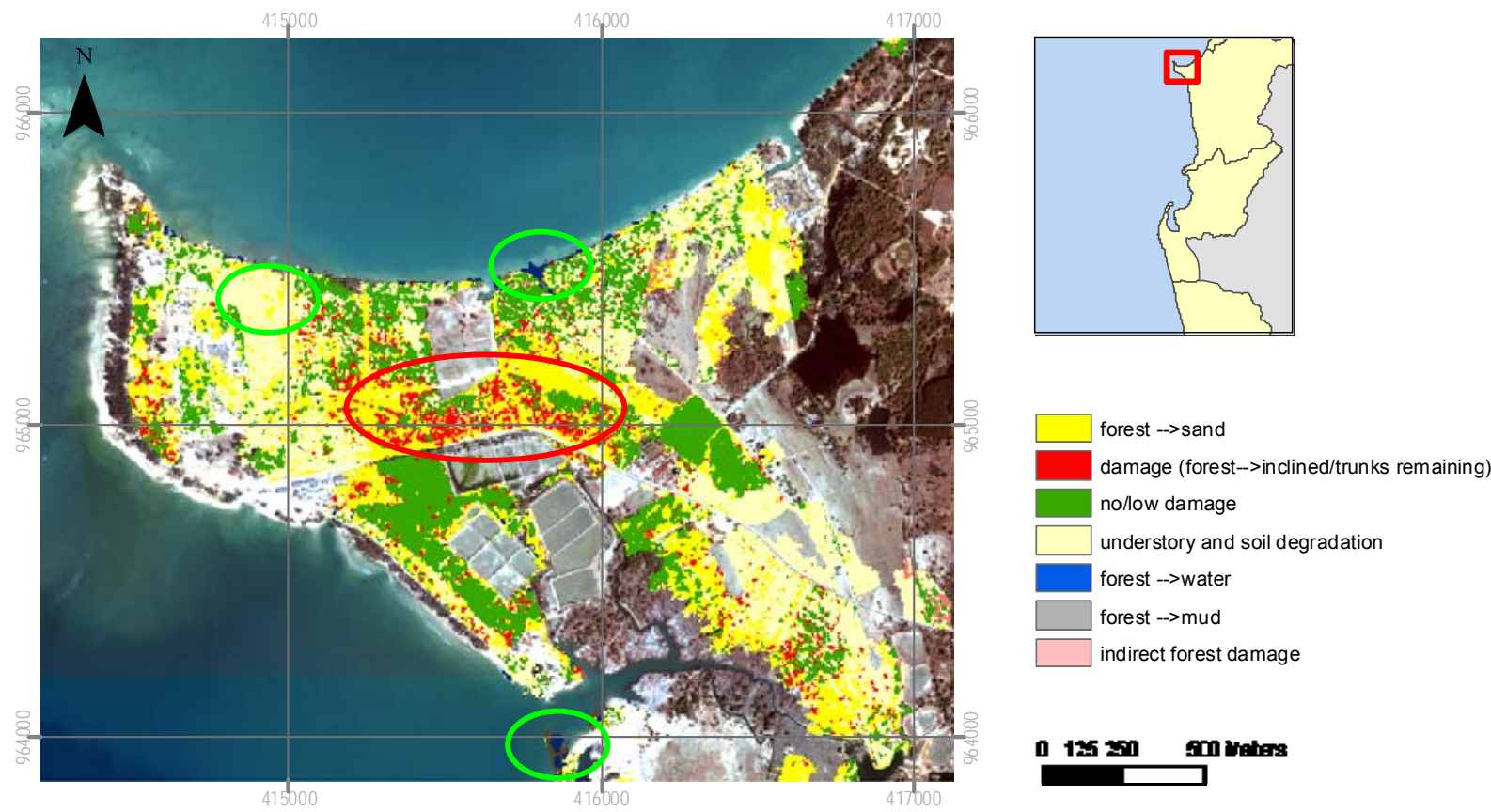

Fig. 14. Human induced land use changes versus tsunami induced changes illustrated for coconut plantation near Pakarang Cape (Khao Lak). Change detection results are based on DMC. Human induced land use changes in the hinterland are highlighted in red, whereas tsunami induced changes near the coast are highlighted in green.

Table 7. Aggregation of change classes for CVA and DMC.

\begin{tabular}{lll}
\hline Method & CVA & DMC \\
\hline $\begin{array}{l}\text { Class ID's*: } \\
\text { Damage/No damage }\end{array}$ & $4-9 / 1-2$ & $3-13 / 1-2$ \\
$\begin{array}{l}\text { Test area N (pixel): } \\
\text { Damage/No damage }\end{array}$ & $1093 / 988$ & $943 / 988$ \\
$\begin{array}{l}\text { Area (ha): } \\
\text { Damage/No damage }\end{array}$ & $417 / 390$ & $500 / 307$ \\
$\begin{array}{l}\text { Area (\%) } \\
\text { Damage/No damage }\end{array}$ & $51.96 / 48.04$ & $61.96 / 38.04$ \\
$\begin{array}{l}\text { Accuracy } \\
\text { Overall accuracies }(\%) /\end{array}$ & $86.50 / 0.73$ & $97.58 / 0.95$ \\
Kappa coefficient & & \\
\hline
\end{tabular}

* class ID's are taken from Table 2 from DMC and Table 4 for CVA, respectively.

and from the problem that not all of the damage information seen during field observations can easily be detected by digital image analysis. Hence, change detection cannot fully substitute field surveys. The advantages of remote sensing techniques include the possibility of (a) providing spatial information which is particularly necessary for areas difficult to access, (b) analysing processes that already have taken place, such as the estimation of tsunami impacts on coastal forests, and (c) developing automated, transferable methods. These criteria make remote sensing an effective tool for hazard analysis. Regarding transferability, the change detection techniques from this study can also be applied for the assessment of ecological impacts from other natural or anthropogenic disasters, e.g. earthquakes, volcanic eruptions, hurricanes or tornados. Additionally, if more image data from the following periods are available, the techniques could also be applied for the estimation of long-term tsunami impacts on coastal forests as well as forest recovery. 


\section{Appendix A}

\section{Accuracy assessment DMC.}

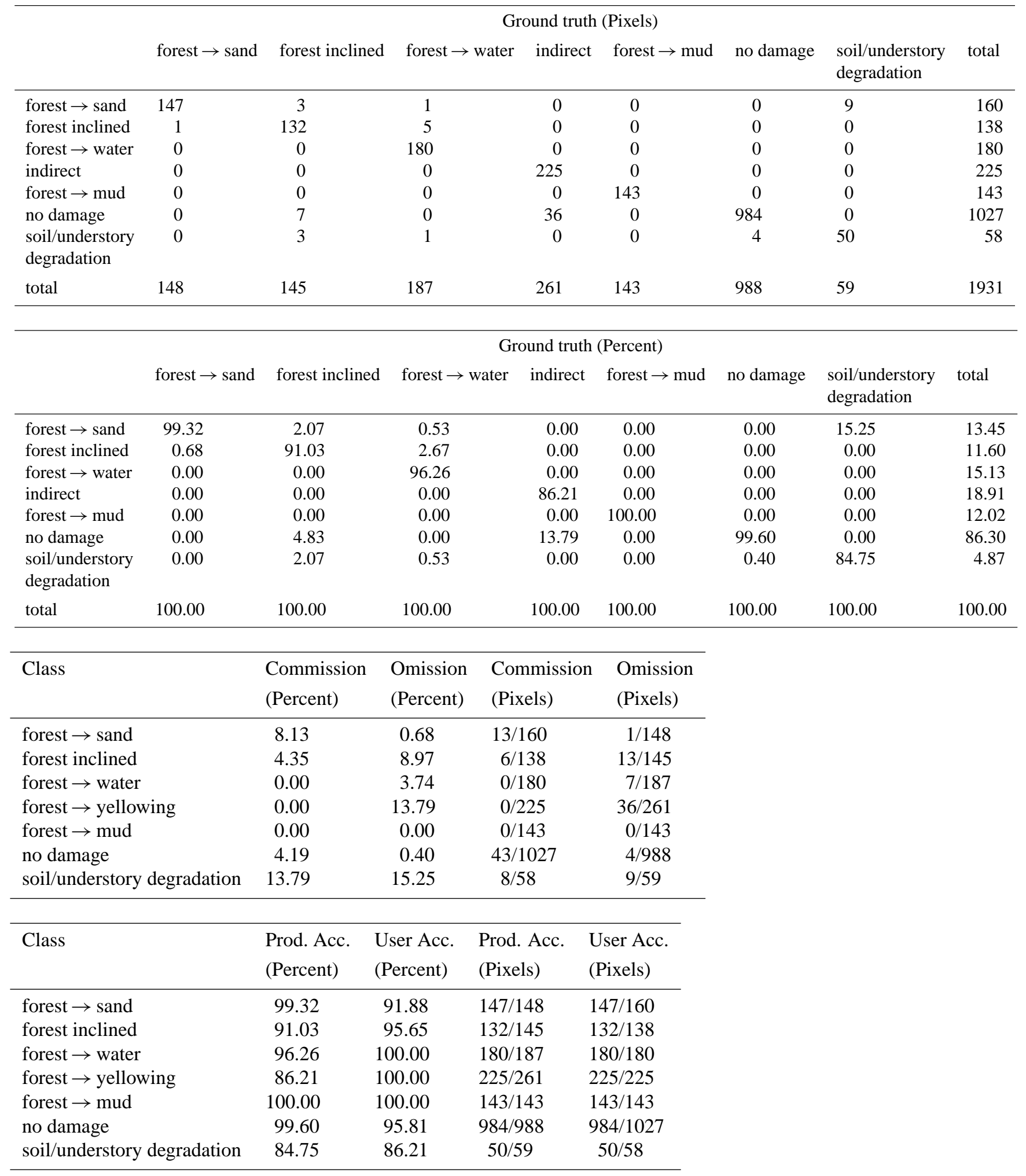




\section{Appendix B}

Accuracy assessment CVA.

\begin{tabular}{lccccrr}
\hline & & \multicolumn{2}{c}{ Ground truth (Pixels) } \\
& understory $\rightarrow$ water/mud & forest $\rightarrow$ mud & degradation & no/low damage & forest $\rightarrow$ water & total \\
\hline understory $\rightarrow$ water/mud & 80 & 0 & 0 & 0 & 9 & 89 \\
forest $\rightarrow$ mud & 6 & 105 & 74 & 0 & 4 & 189 \\
degradation & 15 & 5 & 263 & 8 & 25 & 316 \\
no/low damage & 8 & 8 & 236 & 980 & 20 & 1252 \\
forest $\rightarrow$ water & 41 & 25 & 40 & 0 & 129 & 235 \\
total & 150 & 143 & 613 & 988 & 187 & 2081 \\
\hline
\end{tabular}

\begin{tabular}{lccccrr}
\hline & \multicolumn{5}{c}{ Ground truth (Percent) } \\
& understory $\rightarrow$ water/mud & forest $\rightarrow$ mud & degradation & no/low damage & forest $\rightarrow$ water & total \\
\hline understory $\rightarrow$ water/mud & 53.33 & 0.00 & 0.00 & 0.00 & 4.81 & 4.28 \\
forest $\rightarrow$ mud & 4.00 & 73.43 & 12.07 & 0.00 & 2.14 & 9.08 \\
degradation & 10.00 & 3.50 & 42.90 & 0.81 & 13.37 & 15.19 \\
no/low damage & 5.33 & 5.59 & 38.50 & 99.19 & 10.70 & 60.16 \\
forest $\rightarrow$ water & 27.33 & 17.48 & 6.53 & 0.00 & 68.98 & 11.29 \\
total & 100.00 & 100.00 & 100.00 & 100.00 & 100.00 & 100.00 \\
\hline
\end{tabular}

\begin{tabular}{lllcc}
\hline Class & $\begin{array}{l}\text { Commission } \\
\text { (Percent) }\end{array}$ & $\begin{array}{l}\text { Omission } \\
\text { (Percent) }\end{array}$ & $\begin{array}{l}\text { Commission } \\
(\text { Pixels })\end{array}$ & $\begin{array}{l}\text { Omission } \\
\text { (Pixels) }\end{array}$ \\
\hline understory $\rightarrow$ water/mud & 10.11 & 46.67 & $9 / 89$ & $70 / 150$ \\
forest $\rightarrow$ mud & 44.44 & 26.57 & $84 / 189$ & $38 / 143$ \\
degradation & 16.77 & 57.10 & $53 / 316$ & $350 / 613$ \\
no/low damage & 21.73 & 0.81 & $272 / 1252$ & $8 / 988$ \\
forest $\rightarrow$ water & 45.11 & 31.02 & $0 / 143$ & $58 / 187$ \\
\hline
\end{tabular}

\begin{tabular}{lllll}
\hline Class & $\begin{array}{l}\text { Prod. Acc. } \\
\text { (Percent) }\end{array}$ & $\begin{array}{l}\text { User Acc. } \\
\text { (Percent) }\end{array}$ & $\begin{array}{l}\text { Prod. Acc. } \\
\text { (Pixels) }\end{array}$ & $\begin{array}{l}\text { User Acc. } \\
\text { (Pixels) }\end{array}$ \\
\hline understory $\rightarrow$ water/mud & 53.33 & 89.89 & $147 / 148$ & $147 / 160$ \\
forest $\rightarrow$ mud & 73.43 & 55.56 & $132 / 145$ & $132 / 138$ \\
degradation & 42.90 & 83.23 & $180 / 187$ & $180 / 180$ \\
no/low damage & 99.19 & 78.27 & $225 / 261$ & $225 / 225$ \\
forest $\rightarrow$ water & 68.98 & 54.89 & $143 / 143$ & $143 / 143$ \\
\hline
\end{tabular}




\section{Appendix C}

\section{Confusion matrices DMC (aggregated change classes).}

\begin{tabular}{lrcl}
\hline & \multicolumn{3}{c}{ Ground truth (Pixels) } \\
& damage & no damage & total \\
\hline damage & 900 & 4 & 904 \\
no damage & 43 & 984 & 1027 \\
total & 943 & 988 & 1931 \\
\hline
\end{tabular}

\begin{tabular}{lrcc}
\hline & \multicolumn{3}{c}{ Ground truth (Percent) } \\
& damage & no damage & \multicolumn{1}{c}{ total } \\
\hline damage & 95.44 & 0.40 & 75.71 \\
no damage & 4.56 & 99.59 & 24.29 \\
total & 100.00 & 100.00 & 100.00 \\
\hline
\end{tabular}

\section{Appendix D}

\section{Confusion matrices CVA (aggregated change classes).}

\begin{tabular}{lccr}
\hline & \multicolumn{3}{c}{ Ground truth (Pixels) } \\
& damage & no damage & total \\
\hline damage & 821 & 8 & 829 \\
no damage & 272 & 980 & 1252 \\
total & 1093 & 988 & 2081 \\
\hline
\end{tabular}

\begin{tabular}{lrrr}
\hline & \multicolumn{3}{c}{ Ground truth (Percent) } \\
& damage & no damage & \multicolumn{1}{c}{ total } \\
\hline damage & 75.11 & 0.81 & 39.84 \\
no damage & 24.89 & 99.19 & 60.16 \\
total & 100.00 & 100.00 & 100.00 \\
\hline
\end{tabular}

Acknowledgements. The research presented in this paper builds upon the project "Tsunami Risks, Vulnerability and Resilience in the Phang-Nga Province, Thailand" funded by the German Research Foundation.

Edited by: K.-T. Chang

Reviewed by: two anonymous referees

\section{References}

Bahugana, A., Nayak, S., and Dam, R.: Impact of the tsunami and earthquake of 26th December 2004 on the vital coastal ecosystems of the Andaman and Nicobar Islands assessed using RESOURCESAT AWiFS data, Int. J. Appl. Earth Obs., 10, 229 237, 2008.

Bechteler, A., Pilkama, A., Permana, E., Poellath, J., Prasanai, K., Rahaju, S., Pessala, S., and Alam, S. A.: Coastal Zone Management in Southeast Asia. Case: Mangroves and Tsunami effects in Thailand. Report for ME 451: Tropical Forest Landscape Restoration in Southeast Asia, Fifth International Course on Tropical Forest Ecology and Siliviculture, Thailand, 30 pp., 2006.

Chang, S. E., Eeri, M., Adamas, B. J., Alder, J., Berke, P. R., Chuenpagdee, R., Ghosh, S., and Wabnitz, C.: Coastal ecosystems and tsunami protection after the December 2004 Indian Ocean Tsunami, Earthq. Spectra, 22, 863-887, 2006.

Chatenoux, B. and Peduzzi, P.: Impacts from the 2004 Indian Ocean Tsunami: analyzing the potential protecting role of environmental features, Nat. Hazards, 40, 209-304, 2007.

Chavez, P. S. J., Berlín, G. L., and Sowers, L. B.: Statistical methods for selecting Landsat MSS ratios, J. Appl. Photogr. Eng., 8, 23 30, 1982.

Cochard, R., Ranamukhaarachchi, S. L., Shivakoti, G. P., Shipin, O. V., Edwards, P. J., and Seeland, K. T.: The 2004 tsunami in Aceh and Southern Thailand: A review on coastal ecosystems, wave hazards and vulnerability, Perspect. Plant. Ecol., 10, 3-40, 2008.

Danielsen, F., Sørensen, M. K., Olwig, M. F., Selvam, V., Parish, F., Burgess, N. D., Hiraishi, T., Karunagaran, V. M., Rasmussen, M. S., Hansen, L. B., Quarto, A., and Suryadiputra, N.,: The Asian tsunami: a protective role for vegetation, Science, 310, 643 pp., 2005.

Deeudomchan, K., Potiracha, Y., and Anan, T.: Mangrove change after tsunami in Phang-Nga, Thailand, in: Proceedings of the 27th Asian Conference on Remote Sensing (ACRS 2006), Ulaanbaatar, Mongolia, 1009-1013, 2006.

Department of Marine and Coastal Resources (DMCR) and Thammasat University: Post tsunami impact on mangrove community and status quo of surrounding community: The case study in the area of Mangrove Resource Development Center, Phang Nga, Department of Marine and Coastal Resources, Ministry of natural Resources and Environment, Bangkok, Thailand, 100 pp., 2005.

Department of Marine and Coastal Resources (DMCR): Rapid Assessment of the Tsunami Impact on Marine Resources in the Andaman Sea, Thailand, Phuket Marine Biological Center (PMBC), Phuket, Thailand, 76 pp., 2005.

Department of Marine and Coastal Resources (DMCR): The study on ecosystems and changes of coastal forests affected by the 2004 tsunami, Department of Marine and Coastal Resources, Ministry of natural Resources and Environment, Bangkok, Thailand, 86 pp., 2006.

Ekstrand, S.: Assessment of forest damage with Landsat TM: Correction for varying forest stand characteristics, Remote Sens. Environ., 47, 291-302, 1994.

GeoEye: IKONOS Imagery Products Guide Version 1.5, 21 pp., 2006.

Horne, J. H.: A tasseled cap transformation for IKONOS images, in Proceedings of the ASPRS Annual Conference, Anchorage, 
USA, 5-9 May 2003.

Ioualalen, M., Asavanant, J., Kaewbanjak, N., Grilli, S. T., Kirby, J. T., and Watts, P.: Modelling the 26 December 2004 Indian Ocean tsunami: Case study of impact in Thailand, J. Geophys. Res., 112, C07024, doi:10.1029/2006JC003850, 2007.

Johnson, R. D.: Change Vector Analysis for disaster assessment: a case study of Hurricane Andrew, Geocarto International, 9, 4145, 1994.

Kashio, M.: Tsunami impact assessment in mangroves and other coastal forests in the southern Thailand, FAO Regional Office for Asia and the Pacific, Bangkok, Thailand, 8 pp., 2005.

Kauth, R. J. and Thomas, G. S.: Tasseled Cap - a graphic description of the spectral-temporal development of agricultural crops a seen by Landsat, in: Proceedings of the Machine Processing of Remotely Sensed Data Symposium, Purdue University, West Lafayette, USA, 1976.

Kouchi, K. and Yamazaki, F.: Characteristics of Tsunami-Affected Areas in Moderate-Resolution Satellite Images, IEEE T. Geosci. Remote, 45, 1650-1657, 2007.

Laben, C. A. and Brower, B. V.: Process for enhancing the spatial resolution of multispectral imagery using pan-sharpening, Eastman Kodak Company, Technical Report US Patent \#6011875, 2000.

Lorena, R. B., Dos Santos, J. R., Shimabukoro, Y. E., Brown, I. F., and Kux, H. J. H.: A Change Vector Analysis technique to monitor land use/land cover in SW Brazilian Amazon: Acre State, in: Proceedings of the International Society for Photogrammetry and Remote Sensing (ISPRS), Denver Co, USA, 8 pp., 10-14 November 2002.

Lu, D., Mausel, P., Brondízio, E., and Moran, E.: Change detection techniques, Int. J. Remote Sens., 25, 2365-2407, 2004.

Malila, W. A.: Change Vector Analysis: an approach for detecting forest changes with Landsat, in: Proceedings of the 6th Annual Symposium on Machine Processing of Remotely Sensed Data, West Lafayette, USA, 10 pp., 1980.

Mas, J.-F.: Monitoring land cover changes: a comparison of change detection techniques, Int. J. Remote Sens., 20, 139-152, 1999.

Obura, D. and Abdulla, A.: Assessment of tsunami impacts on the marine environment of the Seychelles, International Union for the Conservation of Nature (IUCN) and United Nations Environment Programme (UNEP), 22 pp., 2005.

Office of Natural Resources and Environmental Policy and Planning: 1 Year After Tsunami: Restoration of Thailand's Natural Resources and Environment, Ministry of Natural Resources and Environment, Bangkok, Thailand, 128 pp., 2005.

Pajimans, K.: Part II Vegetation, in: New Guinea Vegetation, CRISPO, Canberra, Australia, 81 pp., 1976.

Paphavasit, N., Aksornkoae, S., and De Silvia, J.: Tsunami Impact on Mangrove Ecosystem, Thailand Environmental Institute, Nonthaburi, Thailand, 211 pp., 2009.
Phongsuwan, N., Yeemin, T., Worachananant, S., Duangsawasdi, M., Chotiyaputta, C., and Comley, J.: Post-tsunami status of coral reefs and other coastal ecosystems in the Andaman Sea coast of Thailand, in: Status of coral reefs in tsunami-affected countries, edited by: Wilkinson, C., Souter, D., and Goldberg, J., Australian Institute of marine Science, Townville, Australia, 63-78, 2006.

Sirikulchayanon, P., Sun, W., and Oyana, T. J.: Assessing the impact of the 2004 tsunami on mangroves using remote sensing and GIS techniques, Int. J. Remote Sens., 29, 3553-3576, 2008.

Spanner, M. A., Pierce, L. L., Peterson, D. L., and Running, S. W.: Remote sensing of temperate coniferous forest leaf area index: the influence of canopy closure, understory vegetation and background reflectance, Int. J. Remote Sens., 11(1), 95-111, 1990.

Szczucinski, W., Chaimanee, N., Niedzielski, P., Rachlewicz, G., Saisuttichai, D., Tepsuwan, T., Lorenc, S., and Siepak, J.: Environmental and Geological Impacts of the 26 December 2004 Tsunami in Coastal Zone of Thailand - Overview of Short and Long-Term Effects, Pol. J. Environ. Stud., 15, 793-810, 2006.

Tanaka, N., Sasaki, Y., Mowjood, M. I. M., Jinadasa, K. B. S. N., and Homchuen, S.: Coastal vegetation structures and their functions in tsunami protection: experience of the recent Indian Ocean tsunami, Landsc. Ecol. Eng., 3, 33-45, 2007.

Taylor, M.: IKONOS Planetary Reflectance and Mean Solar Exoatmospheric Irradiance, GeoEye, 2009.

United Nations Environment Programme (UNEP): After the Tsunami, Rapid Environmental Assessment, Nairobi, Kenia, 140 pp., 2005.

Vu, T. T., Matsuoka, M., and Yamazaki, F.: Dual-scale approach for detection of tsunami affected areas using optical satellite images, Int. J. Remote Sens., 28, 2995-3011, 2007.

Weissmiller, A., Kristofs, J., Scholzd, K., Anutap, E., and Momens, A.: Change detection in coastal zone environments, Photogramm. Eng. Rem. S., 43, 1533-1539, 1977.

Williams, M., Foryce, F., Paijitprapapon, A., and Charoenchaisri, P.: Arsenic contamination in surface drainage and groundwater in part of the southeast Asian tin belt, Nakhon Si Thammarat Province, southern Thailand, Environ. Geol., 27, 16-33, 1996.

Wong, P. P.: Coastal environment of southeast Asia, in The Physical Geography of Southeast Asia, edited by: Gupta, A., Oxford University Press, Oxford, Great Britain, 16 pp., 2005.

Yanagisawa, H., Kushimura, S., Goto, K., Miyagi, T., Imamura, F., Ruangrassamee, A., and Tanavud, C.: The reduction effects of mangrove forest on a tsunami based on field surveys at Pakarang Cape, Thailand and numerical analysis, Estuar. Coast Shelf S., 81, 27-37, 2009a.

Yanagisawa, H., Kushimura, S., Goto, K., Miyagi, T., Imamura, F., Ruangrassamee, A., and Tanavud, C.: Damage to Mangrove Forest by 2004 Tsunami at pakarang Cape and Namke, Thailand, Pol. J. Environ. Stud., 18, 35-42, 2009b. 